\title{
Differential binding of sulphated insulin to adipocytes and hepatocytes
}

\author{
S.Zeuzem, R. Taylor, L. Agius, A. M. Albisser ${ }^{1}$ and K. G. M. M. Alberti \\ Department of Clinical Biochemistry and Metabolic Medicine, Royal Victoria Infirmary, Newcastle upon Tyne, UK, and \\ 'Biomedical Research Division, The Hospital for Sick Children, Toronto, Ontario, Canada
}

\begin{abstract}
Summary. The polymerization and precipitation of highly purified insulins which causes major problems in portable infusion systems does not occur with sulphated insulin. To compare the biological behaviour of sulphated insulin with that of a neutral highly purified monocomponent insulin, insulin receptor studies were performed on human and rat adipocytes and rat hepatocytes. Sulphated insulin displayed a lower affinity for binding to both human and rat adipocytes compared with neutral insulin, approximately four times the concentration being required to achieve half-maximal displacement of monoiodoinsulin $(p<0.05$ and 0.01 , respectively). A 20 -fold
\end{abstract}

higher concentration of sulphated insulin was required for half-maximal displacement from rat hepatocytes $(p<0.025)$. However, sulphated insulin bound to liver membranes with an affinity more closely resembling that for adipocytes rather than hepatocytes. Differences in the intracellular processing of the negatively charged insulin could account for the observed lower affinity of binding to hepatocytes.

Key words: Sulphated insulin, adipocytes, hepatocytes, insulin receptors.
Highly purified insulins tend to polymerize and precipitate when shaken or exposed to various materials [1]. This property is most relevant when such insulins are used in portable infusion systems [2]. Infusion of partially aggregated insulin results in a loss of glycaemic control and necessitates frequent changes of the insulin reservoir. Long-term studies of intravenous insulin infusion in pancreatectomized dogs have shown that good glycaemic control was achieved only when the insulin in the reservoirs was changed every 3 days $[3,4]$. Subsequent studies have shown that this is not necessary if a sulphated insulin is used [5]. This advantage is most likely to be a result of the stable monomeric nature of sulphated insulin (SI) which does not precipitate under conditions which render conventional insulins visibly turbid [6].

The binding of this modified insulin to insulin receptors has not been examined previously. SI is charged negatively due to the presence of four to six sulphate groups per molecule $[1,7,8]$. It can therefore be anticipated that changes in binding affinity may occur, such as the reduced affinity of SI for antibodies to bovine insulin $[5,9]$. To examine this possibility, the binding-displacement activity of SI has been compared with that of a neutral monocomponent insulin, in human and rat adipocytes and in rat hepatocytes. In addition, binding to highly purified liver membrane and insulin degradation by hepatocytes have been examined.

\section{Materials and methods}

\section{Insulin binding to human adipocytes}

Subcutaneous adipose tissue $(5 \mathrm{~g})$ was obtained from the abdomen of patients, aged $20-65$ years, undergoing gastroenterological surgery. None of the patients suffered from endocrine or metabolic disorders or were taking drugs known to affect metabolism. The study was approved by the Newcastle-upon-Tyne Ethical Committee and informed consent was obtained from the patients.

Adipocytes were isolated by a 90 -min incubation with collagenase $(0.5 \mathrm{mg} / \mathrm{ml})$ in a Hepes buffer ( $\mathrm{pH} 7.4)$ containing $25 \mathrm{mg} / \mathrm{ml}$ human serum albumin. The cells were subsequently washed four times in a HEPES buffer $(10 \mathrm{mmol} / 1$ Hepes, $50 \mathrm{mg} / \mathrm{ml}$ human albumin, $\mathrm{pH} 7.4)$ [10]. Insulin binding to adipocytes $(300 \mu \mathrm{l}$ cell suspension with an adipocyte volume fraction of 0.05 , i. e. about $1 \times 10^{5}$ cells $/ \mathrm{ml}$ cell suspension) was measured after incubation in the Hepes buffer at $37^{\circ} \mathrm{C}$ for $60 \mathrm{~min}$ with $\left[{ }^{125} \mathrm{I}\right]-\mathrm{A}_{14}$ monoiodoinsulin, with and without increasing amounts of unlabelled insulin. The reaction was stopped by adding $10 \mathrm{ml}$ of chilled $0.154 \mathrm{~mol} / 1$ saline and subsequent centrifugation through silicone oil [10]. Non-specific binding accounted for $6.8 \%$ of cell-bound insulin at tracer insulin concentration.

\section{Insulin binding to rat adipocytes}

Isolated fat cells were prepared from epididymal and retroperitoneal fat from fed rats of $190-240 \mathrm{~g}$ using collagenase $(2 \mathrm{mg} / \mathrm{ml})$ in a Hepes buffer containing bovine serum albumin $(50 \mathrm{mg} / \mathrm{ml})$. Binding studies were performed as described for human adipocytes, but using centrifugation through dinonylphthalate to separate cells from medium [11]. For all incubations a Hepes buffer ( $\mathrm{pH} 7.4)$ containing bovine serum $(25 \mathrm{mg} / \mathrm{ml})$ albumin was used. Non-specific binding to rat adipocytes accounted for $10.6 \%$ of cell-bound insulin. 

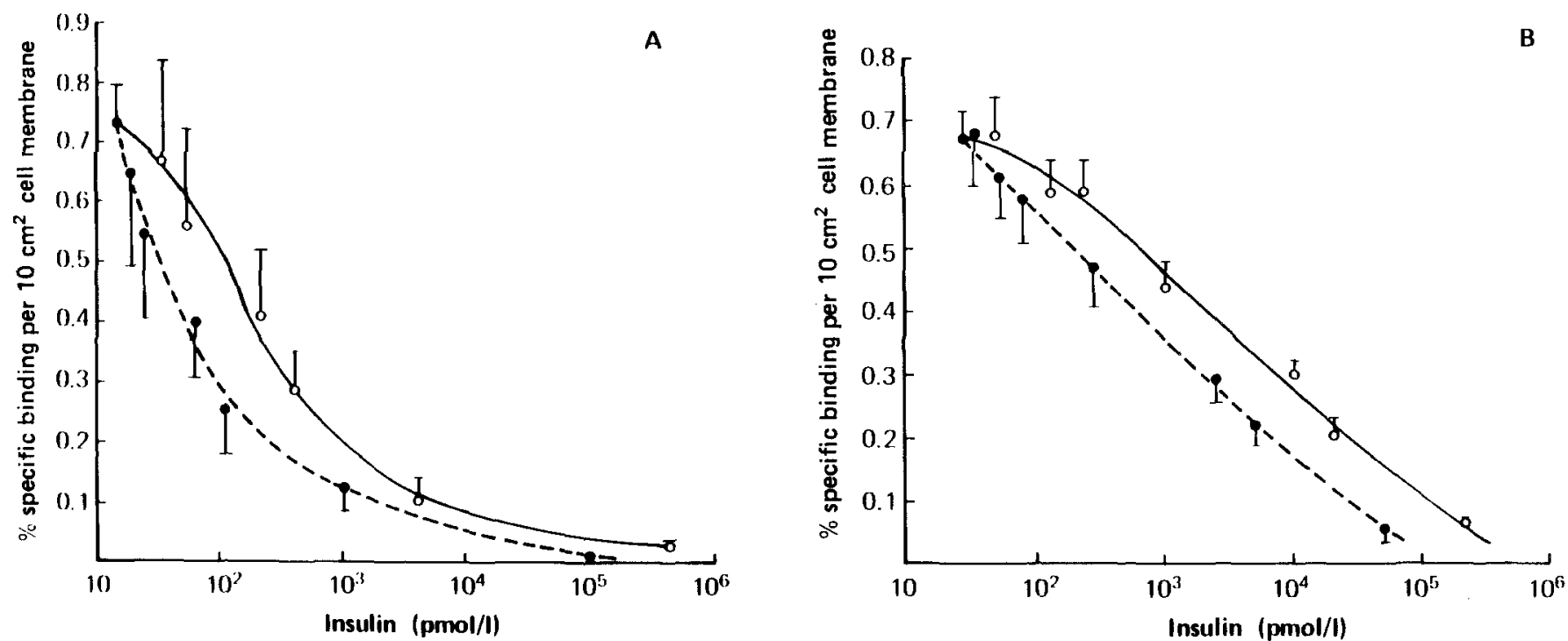

Fig. 1. Specific insulin binding to (A) human adipocytes incubated with $15 \mathrm{pmol} / 1$ monoiodoinsulin at $37^{\circ} \mathrm{C}$ in the absence or presence of sulphated $\left(\mathrm{O}_{-} \mathrm{O}\right)$ or Actrapid $\left(\mathbf{-}_{--}\right)$insulin in increasing concentrations $(n=7)$; and $(\mathbf{B})$ rat adipocytes incubated with 30 pmol/1 monoiodoinsulin at $37^{\circ} \mathrm{C}$ in the absence or presence of sulphate $\left(\mathrm{O}_{-} \mathrm{O}\right)$ or Actrapid $\left(\mathrm{O}_{--}\right)$insulin in increasing concentrations $(n=5)$.
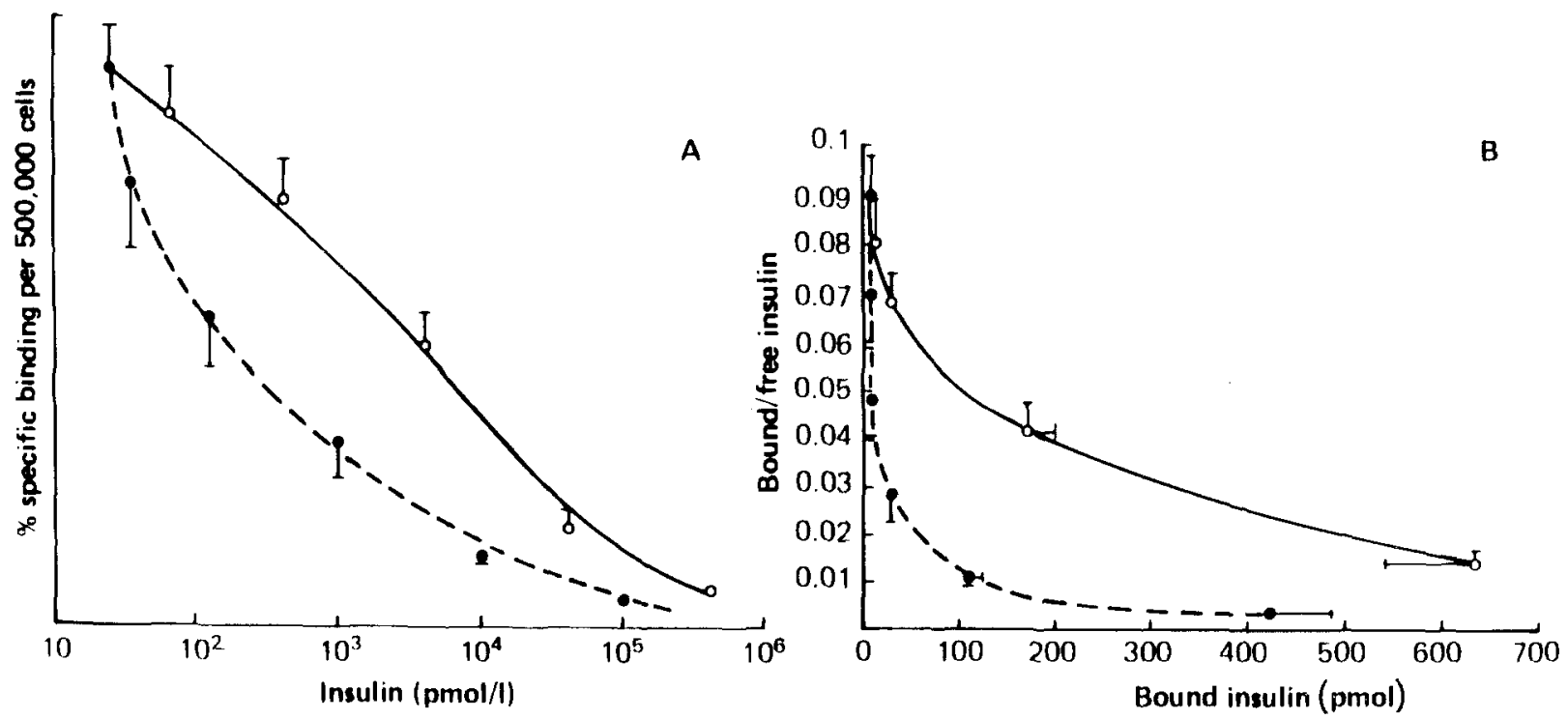

Fig. 2. A Specific insulin binding to rat hepatocytes incubated with $25 \mathrm{pmol} / 1$ monoiodoinsulin at $37^{\circ} \mathrm{C}$ in absence or presence of sulphated $(\mathrm{O}-\mathrm{O})$ or Actrapid $\left(\mathbf{- O}_{--}\right)$insulin in increasing concentrations $(n=6)$. B Scatchard analysis of the data.

The diameter of adipocytes $(n=150)$ was measured at 200 -fold magnification using an eyepiece micrometer (Graticules, Tonbridge, Kent, UK). Surface area and volume were calculated for every measured cell diameter [10]. Results of adipocyte insulin binding studies are expressed as percentage specific binding per $10 \mathrm{~cm}^{2}$ cell membrane surface [12, 13].

\section{Insulin binding to rat hepatocytes}

Hepatocytes were prepared by collagenase perfusion of rat liver [14] and subsequently the isolated cells were suspended in a modified Krebs-Henseleit buffer ( $\mathrm{pH} 7.4)$, containing Hepes $(20 \mathrm{mmol} / \mathrm{l}$ ), $\mathrm{NaHCO}_{3}(10 \mathrm{mmol} / 1)$, bovine serum albumin $(30 \mathrm{mg} / \mathrm{ml})$, bactracin $(800 \mathrm{mg} / \mathrm{ml})$ and gentamicin $(50 \mathrm{mg} / \mathrm{ml})$. Viability was estimated by exclusion of Trypan blue $(0.4 \% \mathrm{w} / \mathrm{v})$ and usually exceeded $90 \%$. Insu- lin binding to hepatocytes (about $1 \times 10^{6}$ cells $/ \mathrm{ml}$ ) was measured after a 40 -min incubation at $37^{\circ} \mathrm{C}$ with ${ }^{125} \mathrm{I}-\mathrm{A}_{14}$ monoiodoinsulin, with and without increasing amounts of unlabelled insulin. Non-specific binding accounted for $10.3 \%$ of cell-bound insulin at tracer insulin concentration.

\section{Insulin degradation by rat hepatocytes}

Total degradation (cellular and extracellular) of $\left[{ }^{125} \mathrm{I}\right]-\mathrm{A}_{14}$ monoiodoinsulin was assessed after a 40-min incubation without and with increasing concentrations of insulin by the trichloracetic acid precipitation method [15]. Data are presented as percentage total degradation, extracellular degradation (as assessed in the presence of $10^{-5} \mathrm{~mol} / 1$ insulin) accounting for $<18 \%$ of total degradation for both sulphated and neutral insulin. 

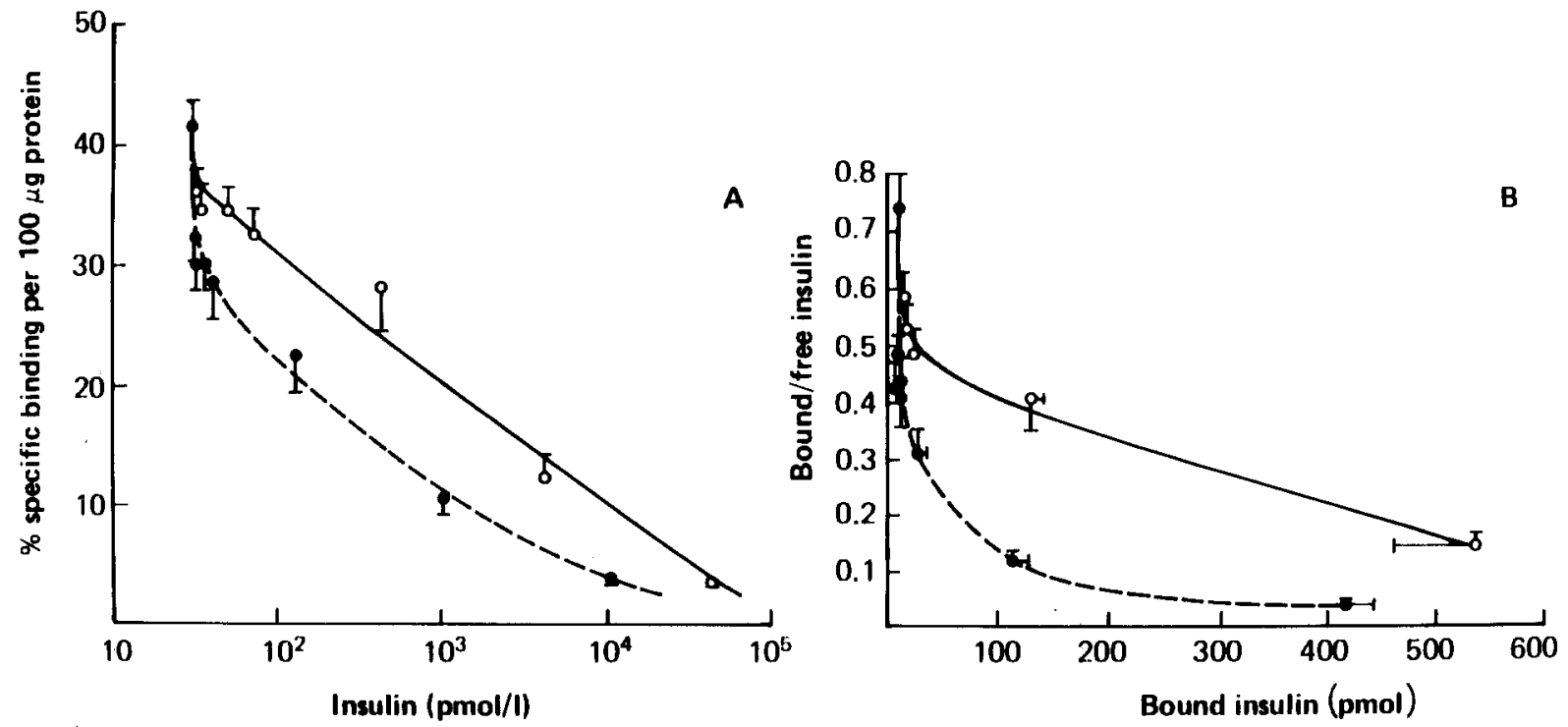

Fig. 3. A Specific insulin binding to rat liver plasma membrane incubated with $25 \mathrm{pmol} / 1$ monoiodoinsulin at $4{ }^{\circ} \mathrm{C}$ in absence or presence of sulphated $(\mathrm{O} O)$ or Actrapid $\left(\mathbf{O}_{---}\right)$insulin in increasing concentrations $(n=6)$. B Scatchard analysis of the data

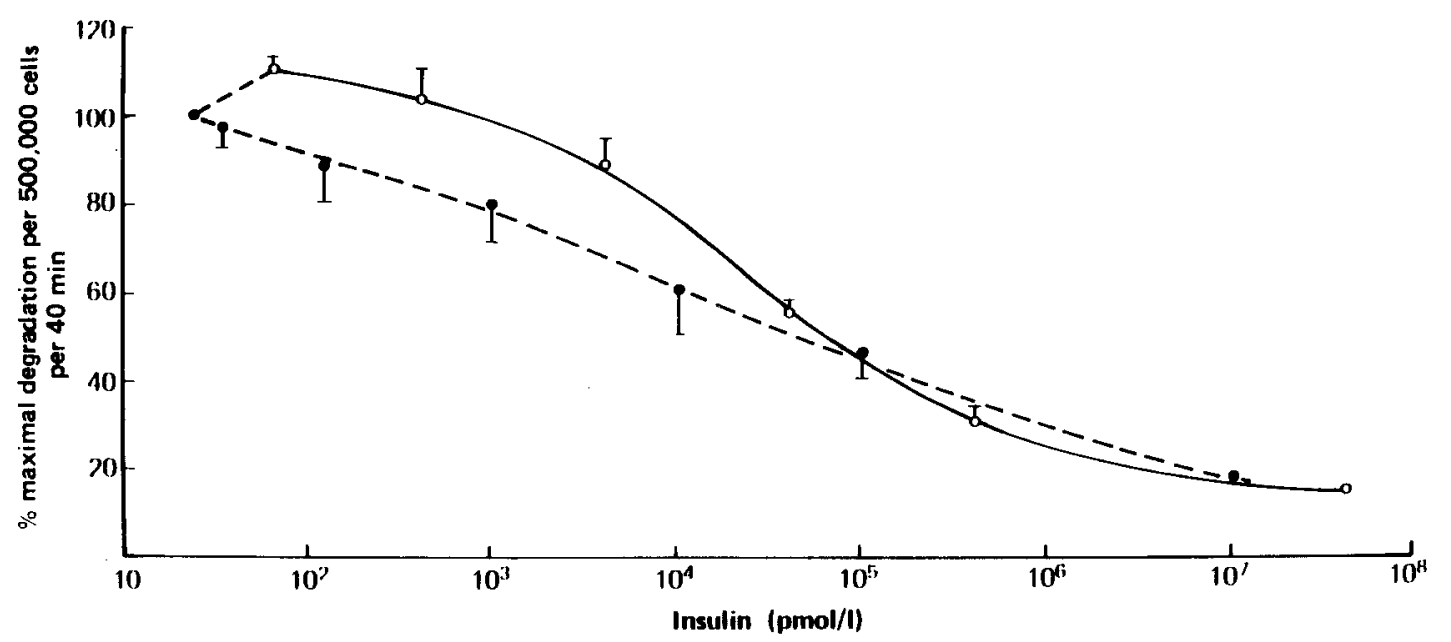

Fig.4. Degradation of monoiodoinsulin by rat hepatocytes incubated at $37^{\circ} \mathrm{C}$ for $40 \mathrm{~min}$ in the absence or presence of sulphated $(\mathrm{O}-\mathrm{O})$ or Actrapid (0-- $)$ insulin in increasing concentrations $(n=5)$

\section{Insulin binding to highly purified liver membrane}

Membranes were prepared by a two phase polymer method, using polyethyleneglycol 6000 and Dextran T500 [16], followed by suspension in a Tris-buffer ( $\mathrm{pH} 7.8$ ), containing bovine serum albumin $(1 \mathrm{mg} / \mathrm{ml})$ and bacitracin $(1 \mathrm{mg} / \mathrm{ml})$. Insulin binding was measured after a 20 - $\mathrm{h}$ incubation at $4^{\circ} \mathrm{C}$. Non-specific binding accounted for $0.96 \%$ of total bound insulin at tracer insulin concentration.

\section{Chemicals}

Sulphated insulin $(6 \mathrm{IU} / \mathrm{mg}$, Connaught Laboratories, Willowdale, Ontario, Canada), Actrapid insulin (26.8 IU/mg, Novo, Copenhagen, Denmark), human serum albumin (Behringwerke, Marburg, FRG), bovine serum albumin, fraction V (Sigma, London) treated with activated charcoal and extensively dialysed before use, crude collagenase (Clostridium histolyticum, batch no.504/22, PL Biochemicals, Milwaukee, Wisconsin, USA), polyethyleneglycol 6000 (British Drug Houses Chemicals, Poole, Dorset, UK), Dextran T500 (Pharmacia, Uppsala, Sweden); bacitracin (Sigma, London); gentamicin (Sigma), $\left.{ }^{125} \mathrm{I}\right]-\mathrm{A}_{14}$ monoiodoinsulin (sp. act. $231 \mu \mathrm{Ci} / \mathrm{mg}$; Novo); dinonylphthalate (British Drug Houses Chemicals); silicone oil (200/50 centistokes, Dow Corning, Midland, Michigan, USA).

\section{Statistical analysis}

All results are presented as mean \pm SEM and statistical analysis was performed using Student's one-tailed t-test.

\section{Results}

Sulphated insulin displayed a lower affinity for binding to both human and rat adipocytes compared with neutral insulin (Fig.1). The insulin concentrations at which half-maximal displacement of tracer occurred were: human adipocytes $234 \pm 87$ versus $59 \pm 15 \mathrm{pmol} / 1(p<$ $0.05)$ and rat adipocytes $5560 \pm 1230$ versus $1216 \pm$ $277 \mathrm{pmol} / 1(p<0.01)$. Expressed as ratios, the relative half-maximal displacement concentrations were $4.0: 1$ for human adipocytes and $4.6: 1$ for rat adipocytes. SI bound to rat hepatocytes with a much lower affinity than did neutral insulin, half-maximal displacement of tracer being observed at $3975 \pm 1426$ versus $191 \pm$ 
$55 \mathrm{pmol} / 1(p<0.025$; ratio 20.8:1). Scatchard analysis suggested that the difference was most marked for the high affinity receptors, the slopes of the high affinity portions of the plots being $-1.78 \pm 0.46$ and $-0.07 \pm$ 0.02 , respectively ( $p<0.025 ;$ Fig. 2 ).

The difference in affinity of binding to liver membranes was not as pronounced as that observed with hepatocytes (Fig. 3), half-maximal displacement binding observed at $972 \pm 150$ versus $154 \pm 12 \mathrm{pmol} / 1$ for SI and neutral insulin, respectively ( $p<0.001$; ratio $6.3: 1$ ).

The ability of SI to inhibit degradation of monoiodoinsulin was much less than that of neutral insulin at concentrations up to $10^{5} \mathrm{pmol} / 1$ (Fig. 4). Inhibition of degradation by $10 \%$ was achieved at $3020 \pm 1213$ $\mathrm{pmol} / 1$ for SI and $122 \pm 43 \mathrm{pmol} / 1$ for neutral insulin $(p<0.05$; Fig. 4). This measurement of degradation includes both cell-mediated and medium degradation. The contribution of the latter, as assessed by degradation in the presence of excess unlabelled insulin, was small $(1.3 \pm 0.3 \%$ for SI and $1.6 \pm 0.5 \%$ for neutral insulin).

\section{Discussion}

We have demonstrated that the binding of SI to the insulin receptor of both human and rat adipocytes is approximately four times less avid than that of a neutral insulin. For rat hepatocytes, the reduction in affinity of SI for the insulin receptor was more pronounced. This difference in binding behaviour between tissues provides a possible physiological basis for the recent observation that $\mathrm{SI}$ is metabolised in at least two different tissues at different rates (M. Nomura and A. M. Albisser, unpublished observations). The clearance rate of SI from the circulation is prolonged in diabetic dogs [5]. As the liver is the major organ responsible for insulin clearance, it is perhaps not surprising that SI demonstrates both reduced affinity for hepatic insulin receptors and a reduced clearance rate in vivo.

If the tissue differences were a consequence of differences in the characteristics of the insulin receptor of liver and fat, it could be anticipated that the binding interaction between SI and liver membranes would resemble that between SI and intact hepatocytes. This was not found to be the case, the ratio of half-maximal displacement concentrations for SI: neutral insulin for liver membranes $(6.3: 1)$ being closer to (although significantly different from) that for adipocytes (4.0:1 and $4.6: 1)$. The lower measured affinity of SI binding to hepatocytes (ratio 20.8:1) is not accounted for by simple change in degradation of the insulin by hepatocytes as at low insulin concentrations SI decreases the rate of degradation of monoiodoinsulin less than does neutral insulin. If the effect of degradation upon the observed binding results was removed, the calculated specific insulin binding at any one SI concentration up to $10^{5}$ pmol/1 would be slightly higher and this would reduce the apparent affinity still further. Therefore there must be differences in the dynamics of intra-hepatocyte handling of SI compared with neutral insulin. More detailed studies of intra-cellular processing of SI, using $\left[{ }^{35} \mathrm{~S}\right]$-sulphated insulin, will be required to elucidate these differences.

The binding characteristics of other synthetic insulin analogues and some naturally occurring unusual insulins have been previously examined. A five fold difference in relative affinity of binding to liver and fat was also seen with hagfish insulin and some of the insulin dimers [17-20]. In the case of hagfish insulin, this difference was assumed to be intrinsic to the insulin receptors of each tissue [17], although studies with liver membranes were not performed to exclude variations in intracellular processing. Porcupine insulin shares with SI both the property of not aggregating in solution and a fourfold lower binding affinity for rat adipocytes than bovine insulin [21]. It has been suggested that the marked tendency to self-aggregation exhibited by native insulin is important in terms of cell surface receptor aggregation and hence insulin action $[22,23]$. The study of SI action in vitro may be expected to explore this hypothesis, and such studies are currently underway. In order to consider fully the implications for insulin - insulin receptor interactions of the binding behaviour of insulin analogues, the molecular structure of the analogue must be defined. The disposition of the sulphate groups within the SI molecule is at present being investigated.

The finding of differential affinities of binding of SI for hepatocytes and adipocytes indicates possibilities for the independent manipulation of different tissues in vivo. Documentation of better glycaemic control during long-term infusion of SI in dogs [15] probably relates to the stability of this insulin in the infusion system, but additional in vivo effects of different tissue affinity are possible. The use of SI in portable infusion systems for diabetic subjects offers some theoretical advantages, particularly with respect to the development of implantable devices with long-term insulin reservoirs.

Acknowledgements. $\mathrm{A}_{14}$ monoiodoinsulin was a gift from Novo. We are grateful to the surgeons and patients of the Royal Victoria Infirmaty for the provision of the adipose tissue biopsies and to the British Diabetic Association for financial support. RT holds a Medical Research Council Training Fellowship.

\section{References}

1. Lougheed WD, Woulfe-Flanagan $\mathrm{H}$, Clement JR, Albisser AM (1980) Insulin aggregation in artificial delivery systems. Diabetologia 19: 1-9

2. Irsigler K, Kritz H (1979) Long-term continuous intravenous therapy with a portable insulin dosage-regulating apparatus. Diabetes 28: 196-203

3. Goriya Y, Bahoric A, Marliss EB, Zinman B, Albisser AM (1979) Glycemic regulation using a programmed insulin delivery device. III. Long-term studies on diabetic dogs. Diabetes 28: 558-564 
4. Goriya Y, Bahoric A, Marliss EB, Zinman B, Albisser AM (1980) Blood glucose control and insulin clearance in unrestrained diabetic dogs portally infused with a portable insulin delivery system. Diabetologia 19: 452-457

5. Nomura M, Zinman B, Bahoric A, Marliss EB, Albisser AM (1984) Intravenous infusions of sulphated insulin normalize plasma glucose levels in pancreatectomized dogs. Diabetes 32: $788-792$

6. Albisser AM, Lougheed WD, Chow JC, Tung AK (1982) A modified insulin for pumps. Diabetes 31 (Suppl 2): 67A

7. Moloney PJ, Aprile MA, Wilson S (1964) Sulphated insulin for treatment of insulin-resistant diabetics. J New Drugs 4: 258-263

8. Thomas JH (1971) Electrophoresis of ${ }^{35} \mathrm{~S}-S$ Sulphated insulin: immunological and biological properties of the H.O. isolated electrophoretic components. Horm Metab Res 3: 207-213

9. Davidson JK, DeBra DW (1978) Immunologic insulin resistance. Diabetes 27: 307-318

10. Pedersen O, Hjollund E, Beck-Nielsen H, Lindskov HO, Sonne O, Gliemann J (1981) Insulin receptor binding and receptor-mediated insulin degradation in human adipocytes. Diabetologia 20: $636-641$

11. Gliemann J, Osterlind K, Vinten J, Gammeltoft S (1972) A procedure for measurement of distribution spaces in isolated fat cells. Biochem Biophys Acta, 286: 1-9

12. Olefsky JM (1976) Decreased insulin binding to adipocytes and circulating monocytes from obese subjects. J Clin Invest 57: $1165-1172$

13. Pedersen O, Hjollund E, Lindskov HO (1982) Insulin binding and action on fat cells from young healthy females and males. Am J Physiol 243: E158-E167

14. Seglen PO (1976) Preparation of isolated rat liver cells. Methods Cell Biol 13: $29-83$

15. Freychet P, Kahn R, Roth J, Neville DM (1972) Insulin interactions with liver plasma membranes: independence of binding of the hormone and its degradation. J Biol Chem 247: 3953-3961
16. Lesko L, Donlon M, Marinetti GV, Hare JD (1973) A rapid method for the isolation of rat liver plasma membranes using an aqueous two-phase polymer system. Biochim Biophys Acta 311: 173-179

17. Gammeltoft S, Kristensen LO, Sestoft L (1978) Insulin receptors in isolated rat hepatocytes: reassessment of binding properties and observations on the inactivation of insulin at $37^{\circ} \mathrm{C}$. $\mathrm{J}$ Biol Chem 253: 8406-8413

18. Gliemann J, Gammeltoft S (1974) The biological activity and the binding affinity of modified insulins determined on isolated rat fat cells. Diabetologia 10: 105-113

19. Freychet P, Brandenburg D, Wollmer A (1974) Receptor-binding assay of chemically modified insulins: comparison of in vitro and in vivo bioassays. Diabetologia 10: 1-5

20. Schuttler A, Brandenburg D (1982) Preparation and properties of covalently linked insulin dimers. Z Physiol Chem 363:317-330

21. Horuk R, Blundell TL, Lazarus NR, Neville RWJ, Stone D, Wollmer (1980) A monomeric insulin from the porcupine (Hystrix cristata), and Old World hystricomorph. Nature 286: $823-824$

22. Jeffrey PD (1982) The interaction of insulin with its receptor: cross-linking via insulin association as the source of receptor clustering. Diabetologia $23: 381-385$

23. Saunders DJ (1982) A new interpretation of structure-function relationships in insulin-receptor interactions. Diabetologia 23 : 386-390

Received 22 July 1983

and in revised form: 11 June 1984

Dr R Taylor,

Department of Clinical Biochemistry and Metabolic Medicine, Royal Victoria Infirmary

Newcastle Upon Tyne, NE1 4LP,

UK 